This is a post-peer-review, precopyedited version of an article published in Contributions to the History of Concepts. The definitive publisher-authenticated version is available online at: http://dx.doi.org/10.3167/choc.2015.100103

Please cite as :

Godin, Benoît. 2015. "Innovation: A Study in the Rehabilitation of a Concept." Contributions to the History of Concepts 10 (1): 45-68. https://doi.org/10.3167/choc.2015.100103. 


\title{
Innovation:
}

\section{A Study in the Rehabilitation of a Concept}

\begin{abstract}
For centuries, innovation was a political and contested concept and linguistic weapon, used against one's enemy. To support their case, opponents of innovation made use of arguments from ethos and pathos to give power and sustenance to their criticisms and to challenge the innovators. However, from the Nineteenth Century the arguments changed completely. Innovation gradually got rehabilitated. This paper looks at one type of rehabilitation: the semantic rehabilitation. People started to re-read history and to redescribe what innovation is. What was bad innovation became good innovation because of long-lasting and beneficial effects, so it was believed.
\end{abstract}

\section{Keywords}

Innovation, intellectual history, conceptual change, political thought, Jeremy Bentham

In recent decades, innovation has become a catchword in discourses, policies and theories, particularly in economic matters (technological innovation). It has not always been so. For 2,500 years, innovation is a contested concept. Innovation is political and subversive of the established order. Of Greek provenance, the word innovation (kainotomia) got into the everyday vocabulary during the Seventeenth Century. In that century, the Reformation was still not complete, according to English puritans ${ }^{1}$ who started accusing the bishops of innovating or bringing the Church back to Rome doctrine and discipline. From then on, innovation shared a place with heresy and revolution in the vocabulary of the critics of or opponents to change. ${ }^{2}$ Such a negative connotation of innovation continued until the Twentieth Century.

Innovation seems to have escaped the attention of historians. No intellectual history exists of the concept innovation. The literature studies many concepts of change like revolution, crisis, progress and modernity, but not innovation. Is innovation only a word - a mere word - in the vocabulary of adherents to the status quo - Churches, Kings and their supporters - and devoid of sociological meaning?

\footnotetext{
1 Anthony Milton, Catholic and Reformed: The Roman and Protestant Churches in English Protestant Thought, 1600-1640 (Cambridge: Cambridge University Press, 1995).

${ }^{2}$ Benoît Godin, Innovation Contested: The Idea of Innovation Over the Centuries (London: Routledge) 2015.
} 
In a certain sense, yes. Before the twentieth century, there existed no theory of innovation. Innovation was a term of limited theoretical content, a linguistic weapon used against one's enemy. In another sense, no. The opponents of innovation provided the first image of innovation and innovators, one that lasted until the Twentieth Century. What constitutes innovation and who is an innovator were defined by the enemies of innovation and innovators: an innovator is a supporter of intentional change, as opposed to change from God or from political and ecclesiastical authorities. Innovation is subversive to the established order. It is against this pejorative image or representation of innovation that innovators (revolutionaries, inventors and others) had to struggle when they started making use of the concept in a positive sense in the Nineteenth Century.

The opponents of innovation make use of two kinds of arguments to support their case. First, ethos: respect is due to tradition, authority and order. "King and novelties here doe stand in opposition against the other”, claims the puritan Henry Burton, during the ‘innovation controversy’ in mid-Seventeenth Century England (1636-41). ${ }^{3}$ The second argument used against innovation is pathos. A series of epithets (e.g. heretic) and associations (e.g. revolution) are offered to heighten the emotions, disqualify the innovator and dramatize the consequences of innovation. However, by the Nineteenth century a third kind of argument enters the discourses on innovation: logos. People start to talk of and about innovation in different terms: innovation is useful and progressive. It brings benefits, if introduced correctly. Innovation is instrumental to political, social and material progress. This rehabilitation occurred between c.1750 and c.1850, that period of history Reinhart Koselleck designates as Sattlezeit, when many words changed meanings due to a "shift in the conception of time and a reorientation towards the future".

Instrumentality is only part of the story of this rehabilitation. At the same time, the rehabilitation of innovation makes use of a new rhetorical move: re-description. People start to re-read history, including contemporary history, and redefine innovation in new terms. Writers start claiming that innovation is an abused word, the "war cry of fools",

\footnotetext{
${ }^{3}$ Henry Burton, For God and the King (Amsterdam: Theatrum Orbis Terrarum; Norwood (NJ): W. J. Johnson [1976], 1636), 100.
} 
that of a "short-sighted mind". What was considered bad innovation shifts to good innovation.

This article is about the semantic rehabilitation of innovation. The first section two sections document the representation of innovation from Antiquity to the sixteenth century, namely when innovation changed meaning to the negative. The rest of the article discusses, in turn, the arguments used against innovation and innovators before the Nineteenth century: ethos and pathos respectively. The last section turns to logos. I concentrate on Jeremy Bentham's Book of Fallacies as a crucial step in the rehabilitation of innovation, from a linguistic weapon to a concept in its own right. ${ }^{4}$ In most of his writings, Bentham positions himself as a 'legislator' of definitions. ${ }^{5}$ He took on the task of correcting linguistic abuses and fixing language. To Bentham, innovation is such an abused word that it deserves rehabilitation.

Over the years, I have collected over 400 documents that have titles containing innovation, from the Reformation to the late nineteenth century. I have also studied hundreds of titles from the twentieth century, up to c.1975-80, namely at the time the idea of innovation crystallized in modern theories. In a second phase, I have supplemented these titles with searches through hundreds of other texts online, using archival sources like Perseus Digital Library, British History Online, Early English Books Online (EEBO), Eighteenth Century Collection Online (ECCO), Gallica (Bibliothèque Nationale de France), the ARTFL Project and Google Books (Ngram). The article is based on the analysis of these documents.

\footnotetext{
${ }^{4}$ Jeremy Bentham, The Book of Fallacies: from Unfinished Papers of Jeremy Bentham (London: John and H. L. Hunt, 1824).

${ }^{5}$ In many diverse writings, and particularly in his Book of Fallacies, Bentham offers a project for a neutral vocabulary. Yet in general, Bentham is not part of the history of philosophical projects on a universal language, like that of Mary M. Slaughter, Universal Languages and Scientific Taxonomy in Seventeenth Century England (Cambridge: Cambridge University Press, 1982). Apart from C.K. Ogden, Bentham's Theory of Fictions (Abingdon: Routledge [2000], 1932], only brief mentions of Bentham's 'applied' rhetoric are made from time to time, as in Kenneth Burke, A Rhetoric of Motives (California: University of California Press, 1950); David Spadafora, The Idea of Progress in Eighteenth-Century Britain (New York: Yale University Press, 1990); Albert O. Hirschman, The Rhetoric of Reaction: Perversity, Futility, Jeopardy (Cambridge, Mass.: Harvard University Press, 1991). One reviewer of this paper pointed to a recent reference that I have not read yet: Guillaume Tusseau, Jeremy Bentham: La guerre des mots (Paris, Dalloz, 2011).
} 


\section{Emergence of the Concept}

From its very emergence in Ancient Greece, the concept of innovation (kainotomia) had a political connotation. As "introducing change into the established order", innovation was subversive, or revolutionary, as we say today. Such were Plato's and Aristotle's meanings; one focusing on cultural innovation (games, music) and its effect on society, ${ }^{6}$ the other on changes to political constitutions. ${ }^{7}$ Certainly, there were a few positive uses of the concept in classical Greece. Xenophon's Ways and Means on 'political economy' is one example. Xenophon's use of kainotomia is literal - later writers used the concept in a metaphorical sense. The word is a combination of kainos (new) and the radical tom (cut; cutting). Xenophon's use of innovation is “making new cuttings”, namely opening new mine galleries. Xenophon's objective was to increase the revenues of the city of Athens. Plutarch in Lives of Greeks and Romans is another example of positive uses of the concept. ${ }^{8}$ But in general, innovation is negative. In general too, innovation is a word with few occurrences among ancient writers.

The political and contested connotation survives, or rather was revived during the Reformation (see below). In the meantime, the concept made its entry into Latin vocabulary, with a positive meaning. In contrast to the Greeks, the Romans had no word for innovation, although they had many words for novelty (novitas, res nova). In addition, the verb novare carries a pejorative meaning similar to kainotomia, depending on the context. Yet, from the $4^{\text {th }}$ century, Latin writers, first of all Christian writers and poets, coin in-novo, which means renewing, in line with other Christian terms of the time:

\footnotetext{
6 "When the programme of games is prescribed and secures that the same children always play the same games and delight in the same toys in the same way and under the same conditions, it allows the real and serious laws also to remain undisturbed; but when these games vary and suffer innovations ... [children] have no fixed and acknowledged standard of propriety and impropriety" (Plato, The Laws, VII, 797b).

7 "Even a small thing may cause changes. If for example people abandon some small feature of their constitution, next time they will with an easier mind tamper with some other and slightly more important feature, until in the end they tamper with the whole structure ... The whole set up of the constitution [is] altered and it passed into the hands of the power-group that had started the process of innovation" [neoterizein] (Aristotle, Politics, X, xii, 1316b).

${ }^{8}$ Mention needs to be made to Polybius too. In his Histories, Polybius coins kainopoein, the meaning of which is "making new", a term that he applies to himself as inventor of a new kind of history.
} 
regeneration, reformation, renovation. ${ }^{9}$ Innovo has no future connotation as such, although it brings a 'new order'. Innovo refers to the past: going back to purity or the original soul. The Vulgate was influential here. In 382, Pope Damasus I commissioned Saint Jerome to produce a 'standard' version of the Vetus Latina, which he did using original Greek and Hebrew texts. Four books in the Vulgate make use of innovo in a spiritual context (Job, Lamentations, Psalms, Wisdom).

Revolution and renewing are the two poles of a spectrum of meanings that define innovation in the following centuries, both in dictionaries and lay discourses - contrary to political thought there was no theoretical work on innovation before the late $19^{\text {th }}$ century. Renewing points to the past (return to the old, changing or renewing the old) and revolution points to the future (introducing something new, entirely new). For example, Catholic Popes in the $15^{\text {th }}$ century used innovation in a legal context as renewing previous statutes, and Machiavelli did so in the sense of imitation. In spite of his 'revolutionary' political morality, Machiavelli's meaning of innovation is introducing new laws similar to those of great rulers in the past. ${ }^{10}$ On the other hand, reformers and counter-reformers from the $16^{\text {th }}$ century used the concept as a word of accusation for changing things with 'revolutionary' consequences impending.

\section{The Reformation}

Innovation began with both positive and negative meanings, as discussed above, but subsequently lost this valence when it moved to the politico-religious sphere of the Reformation. In order to contribute to the making of the Reformation, royal and ecclesiastical authorities started using innovation in discourse. In 1548, Edward VI, King of England and successor to Henry VIII, issued a Proclamation Against Those That

\footnotetext{
${ }^{9}$ Gerhart B. Ladner, The Idea of Reform: Its Impact on Christian Thought and Action in the Age of the Fathers (Cambridge: Harvard University Press).

${ }^{10}$ Niccolo Machiavelli, The Discourses, Bernard Crick and Leslie J. Walker (ed.) (London: Penguin, 2003); Niccolo Machiavelli, The Prince, Quentin Skinner and Russell Price (ed.) (Cambridge: Cambridge University Press, 1988).
} 
Doeth Innouate. The proclamation places innovation in context, constitutes an admonition not to innovate and imposes punishments on offenders: ${ }^{11}$

\begin{abstract}
Considering nothing so muche, to tende to the disquieting of his realme, as diversitie of opinions, and varietie of Rites and Ceremonies, concerning Religion and worshippyng of almightie God ...; [considering] certain private Curates, Preachers, and other laye men, contrary to their bounden duties of obedience, both rashely attempte of their owne and singulet witte and mynde, in some Parishe Churches not onely to persuade the people, from the olde and customed Rites and Ceremonies, but also bryngeth in newe and strange orders ... according to their fantasies ... is an evident token of pride and arrogance, so it tendeth bothe to confusion and disorder ...: Wherefore his Majestie straightly chargeth and commandeth, that no maner persone, of what estate, order, or degree soever he be, of his private mynde, will or phantasie, do omitte, leave doune, change, alter or innovate any order, Rite or Ceremonie, commonly used and frequented in the Church of Englande ... Whosoever shall offende, contrary to this Proclamation, shall incure his highness indignation, and suffer imprisonment, and other grievous punishementes.
\end{abstract}

The proclamation is followed by the Book of Common Prayer, whose preface enjoined people not to meddle with the "folly" and "innovations and new-fangledness" of some men. ${ }^{12}$ A hundred years later, King Charles prohibited innovation again, ${ }^{13}$ and the Church produced lists of forbidden innovations, ${ }^{14}$ required bishops to visit parishes to enforce the ban, instructed bishops and archbishops as well as doctors (universities) and school-masters to take an oath against innovations and ordered trials and prosecuted the “innovators". 15 Advice books and treatises for princes and courtiers supported this understanding, and included instructions not to innovate. Books of manners urged people

\footnotetext{
${ }^{11}$ England and Wales. Sovereign (Edward VI), A proclamation against those that doeth innouate, alter or leaue doune any rite or ceremonie in the Church, of their priuate aucthoritie: and against them which preacheth without licence, set furth the .vj. daie of Februarij, in the seconde yere of the Kynges Maiesties most gracious reigne (Excusum Londini: In aedibus Richardi Graftoni regij impressoris. Cum priuilegio ad imprimendum solum, 1548).

${ }^{12}$ Church of England, The booke of common prayer and administracion of the Sacramentes, and other rites of the Churche: after the use of the Churche of England (London: in officinal Edouardi Whitchurche [and Nicolas Hill] Cum privilegio ad imprimendum solum, 1549).

${ }^{13}$ England and Wales. Sovereign (Charles I), The King's Proclamation on Religion, in S. R. Gardiner (ed.), The Constitutional Documents of the Puritan Revolution, 1625-1660 (Oxford: Clarendon Press [1906], 1641).

${ }^{14}$ Church of England, A copie of the proceedings of some worthy and learned divines, appointed by the Lords to meet at the Bishop of Lincolnes in Westminster touching innovations in the doctrine and discipline of the Church of England. Together with considerations upon the Common prayer book (London: no editor, 1641).

${ }^{15}$ Church of Scotland, Act of the Commission of the General Assembly, Against Innovations in the Worship of God (Edinburgh: no editor, 1707).
} 
not to meddle with innovation. Speeches and sermons spoke against innovation, religious and political.

The Reformation was a key moment in the history of the concept of innovation. At a time when the Reformation was incomplete and still in the making, the Catholics accused the reformers of innovating. The Puritans served the same argument to the Protestant Church, accused of bringing the Church back to Catholicism. The word served both sides of the discourse. It was precisely in the context of the Reformation that the concept entered everyday discourse. The English puritan Henry Burton was an emblematic writer. Every later argument on innovation would be found in the pamphlet For God and the King, ${ }^{16}$ the sum (with additions and enhancements) of two sermons preached on November 5 "to teach my people obedience to both" God and the King in these times of "innovations tending to reduce us to that Religion of Rome”. Innovators are those who transgress the disciplinary order and intend to change it for evil purposes, in the present case bringing the Protestant Church back to Catholicism doctrine and discipline. Innovating is a private liberty - as heresy is - that creeps imperceptibly and, with time, leads to dangerous consequences. Archbishop William Laud and his supporters (Peter Heylin, Christopher Dow) produced replies that carried the complete opposite argument of Burton's: WE are not innovating but bringing the Church back to purity. Burton was brought to the Court, put into prison and had his ears cut off.

This was only a beginning. Soon the meaning of innovation was to be enlarged. First, to the political; in the $17^{\text {th }}$ century, the monarchists accused the republicans of being “innovators”. Such was the accusation made against Henry Neville in England and his pamphlet Plato Redivivus: or, a Dialogue Concerning Government. ${ }^{17}$ Innovation is revolutionary ... and violent. No republican - no citizen in fact - thought of applying the concept to his own project. Innovation is too bad a word for this. In contrast, and precisely because the word is morally connoted, the monarchists use and abuse the word

\footnotetext{
${ }^{16}$ Henry Burton, For God and the King.

${ }^{17}$ Henry Neville , Plato redivivus, or, A dialogue concerning government wherein, by observations drawn from other kingdoms and states both ancient and modern, an endeavour is used to discover the present politick distemper of our own, with the causes and remedies ... , Second edition (London: Printed for S.I. and sold by R. Dew, 1681).
} 
and label the Republican as an innovator. ${ }^{18}$ This rhetorical or linguistic practice continued until the French Revolution - and later.

Second, innovation widens its meaning to the social. The social reformer or socialist of the $19^{\text {th }}$ century is called a "social innovator", as William Sargant puts it in Social Innovators and Their Scheme. ${ }^{19}$ His aim is to overthrow the social order, namely private property. Innovation is a scheme or design in a pejorative sense - as it is a conspiracy (project or plan or plot or machination) in political literature. This connotation remained in vocabulary until late in the $19^{\text {th }}$ century - although some writers discuss social innovation using the positive idea of (social) reform. For example, in 1888, a popular edition of the Encyclopedia Britannica included a long article on communism which begins as follows: "Communism is the name given to the schemes of social innovation which have for their starting point the attempted overthrow of the institution of private property”. 20

Everyone shares this representation of innovation. Natural philosophers, from Francis Bacon onward, never use innovation to talk of what is certainly the most innovative project in science: the experimental method. Equally, few artisans and inventors talk of their invention in terms of innovation. Innovation is political.

\section{Ethos}

Opponents to religious, political and social change appeal to ethos as one of the two basic types of argument against innovation. The argument takes many forms. One is respect due to authorities, political and religious. The King himself (e.g. Charles I) denies the charge of innovation made by Parliament: "our true meaning and intention is, not to admit anie innovation eyther in Religion or Lawes, but carefully to maintayne the puritie

\footnotetext{
${ }^{18}$ Anonymous (W.W.), Antidotum Britannicum: or, a counter-pest against the Destructive Principles of Plato Redivivus ..., against ALL INNOVATORS (London: Richard Sare; 1681); Thomas Goddard, Plato's Demon: or, the State-Physician Unmaskt; Being a Discourse in Answer to a Book call'd Plato Redivivus (London, H. Hill, 1684).

${ }^{19}$ William L. Sargant, Social Innovators and Their Schemes (London: Smith, Elder and Co, 1858).

${ }^{20}$ Encyclopedia Britannica, Communism, T. S. Baynes (ed.), volume 6, third edition (New York: Henry G. Allen, 1888): 211.
} 
of Religion already profest and established”. ${ }^{21}$ The much contested English Archbishop William Laud had to defend himself too, by way of a series of principles issued in the King's name. ${ }^{22}$ Opponents of innovation - puritans, ecclesiasts, royalists and pamphleteers - regularly repeat the admonitions of monarchs in support of their own case against innovators.

Respect is due to authority, but to tradition and custom too. One cannot change what time and wisdom have established. Robert Poyntz, Knight of the Bath, in one of the very first documents with innovation in its title, develops a whole discourse defending the English monarchy against the republican "innovators" on the basis of the common law. "Respect is to be had unto the times of old". ${ }^{23}$ During the French Revolution, the "formes antiques” were regularly emphasized against those whom the monarchists call innovators and in support of the "constitution immortelle ... depuis quatorze siècles” [constitution immortal for fourteen centuries]. ${ }^{24}$ Science is no exception: the "superficie” [superficial], "l'éclat" [glamour] of innovations is opposed to the principles of the ancients. ${ }^{25}$ Philosophes like Descartes, and Voltaire are regularly accused of being “novateurs”, ${ }^{26}$ of “vain desire of Innovation”. 27

\footnotetext{
${ }^{21}$ England and Wales. Sovereign (Charles I), Charls by the grace of God, King of Scotland ...: for-sameikle as we are not ignorant of the great disorders which haue happened of late within this our ancient kingdome of Scotland, occasioned, as is pretended, vpon the introduction of the service booke, booke of canons, and high commission, thereby fearing innovation of religion and laws ..., Given at our court of Greenwich, the twentie eyght day of June, and of our reygne the thirteenth yeare. Reproduction of original in the Town House (Aberdeen, Scotland: Charter Room, 1638).

${ }^{22}$ Church of England, Constitutions and Canons Ecclesiasticall; Treated upon by the Archbishop of Canterbury and York, Presidents of the Convocations for the respective Provinces of Canterbury and York, and the rest of the Bishops and Clergie of those Provinces (London: Robert Barker, 1640).

${ }^{23}$ Robert Poyntz, A VINDICATION OF MONARCHY and the Government long established in the Church and Kingdom of England, Against The Pernitious Assertions and tumultuous Practices of the Innovators during the last Parliament in the REIGN of CHARLES the I (London: Roger Norton, 1661), 12.

${ }^{24}$ Charles Marie Thérèse Léon Tinseau-D’Amondans, Parallèle des deux déclarations du Roi, faites le 23 juin 1789 et des principales innovations proposées de nos jours, avec la véritable constitution françoise (Paris, 1792), 77.

${ }^{25}$ Jean Maurin, Lettre de Mr Maurin, docteur en médecine, à son ami. Par laquelle on connoit les raisons qui ont engagé les Anciens à n'admettre point de Circulation du sang, \& celles des Novateurs à se détacher des sentimens des Anciens (Paris?, no editor 1696), 24.

${ }^{26}$ Edouard Bardagé, Mandement de Monseigneur L'Illustrissime et Revendissime Evêque de Nevers, conseiller du Roy en ses conseils, contre les novateurs, les livres jancénistes et la philosophie de Descartes (Nevers: Philippe Ignace Chaillot, 1707), 4.

27 Thomas Bancroft, The Danger of Political Innovation and the Evil of Anarchy (Chester, Printed and sold by the Booksellers1792), 10.
} 
In this context, the use of history to support one's case is a regular tactic of innovation's opponents. Analogies and examples taken from the past, including antiquity, abound in the mouths of those in support of the status quo, until the Nineteenth century. For example, in Innovations, a lecture delivered in Liverpool in 1868, Reverend Richard Frederick Littledale looks at twelve contested practices or changes introduced in the Church and, using Joseph Esmond Riddle's Manual of Christian Antiquities (1843), demonstrates that all of them are hundreds or even thousands of years old, and therefore not innovations. 28 "But some of you will say", claims Littledale, "practically they are Innovation, for they are new to us, and Innovations in religion are bad things”. But such an argument "is a very dangerous argument for ... the Reformation” which "was an Innovation, and on the very largest and most startling scale” : ${ }^{29}$ the reformers burned and ruined churches; they turned chalices into drinking cups, altar-stones into pavements, Church vestments into counterpanes, fonts into dog-troughs, and the like; they stopped the daily service of prayer; they invented the pew-system; they sold (for a fee) the sacraments; they ruined schools and monasteries and burned university libraries. 30 "Our position is briefly this: The religion we teach is an old one ... We are not innovating”. ${ }^{31}$

The old as a weapon in argument has been much studied. Yet, "even the old admitted of nuances, contradictions, and contested definitions, depending upon the context”. ${ }^{32}$ What characterizes innovation is that the argument from ethos stresses at the same time the intentional or purposive character of the innovator. As the Scottish philosopher Thomas Reid put it: Innovation is a "liberty which, even when necessary, creates prejudice and misconstructions, and which must wait the sanction of time to authorize it”. 33

\footnotetext{
${ }^{28}$ Prayers for the dead, choral service, the sign of the cross, weekly offertory, daily celebration of the holy communion, elevation of the host, turning to the east in prayer or at the Creed, division of the sexes, mixed chalice in holy communion, adjuncts of worship like incense, vestments and lights on the altar.

${ }^{29}$ Richard Frederick Littledale, Innovations: a Lecture Delivered in the Assembly Rooms, Liverpool, April 23rd, 1868 (Oxford: A. R. Mowbray; London: Simpkin, Marschall \& Co, 1868), 15.

${ }^{30}$ Littledale, Innovations, 22-24.

${ }^{31}$ Ibid, 27.

32 Daniel Woolf, The Social Construction of the Past: English Historical Culture 1500-1730 (Oxford: Oxford University Press, 2003), 44. See also Daniel R. Woolf, In Praise of Older Things: Notions of Age and Antiquity in Early Modern England, in A. T. Grafton and J. H. M. Salmon (eds.), Historians and Ideologues: Essays in Honor of Donald R. Kelley (New York: Rochester: University of Rochester Press, 2001), 123-53.

33 Thomas Reid, On the Danger of Political Innovation (The Glasgow Courier, 1796)
} 
That innovation is a liberty is a recurrent theme in the literature of the time, usually expressed in terms of "private” opinion. In England, religion is full of the argument, starting with Edward VI in his proclamation Against Those that Doeth Innouate. ${ }^{34}$ Private opinion abounds in politics too, for example during the controversy on republicanism in seventeenth century England.

The argument from liberty or private opinion makes it clear that innovation is a secularized form of the idea of heresy. Opponents to both heresy and innovation accuse the enemy of similar acts: rebellion, civil wars, instability and disorder. The lexicon of heresy if also full of pejorative references to novelty: art and craft, invention, and "love of novelty". Innovation is a liberty, as Reid put it, a personal vision or action which threatens authority and orthodoxy. There are boundaries that no-one should cross.

To others, private opinion is a matter of invention and imagination (fancy). Both concepts - invention and imagination - were pejorative until the Nineteenth Century. King Charles of "private fancies”; Burton of "humane invention” and "man’s devising”; Peter Heylin from the High Commission, of "fancie" and "owne devising”. ${ }^{35}$ Other similar attacks use words like eutopia, utopia, fantastical, sophistical and philosophical.

In the political sphere, private opinion take the meaning of a private design or conspiracy (plot, scheme and design are the words used). "The means of effecting such ... change[s] are: plots, conspiracies, sedition, rebellion, civil war, bloodshed and massacre”. 36 "Design” (connotation: subversive) and “scheme” (connotation: suspicious) are recurrent words used against innovation. Machination (“of wicked ingenuity”) is another. Edmund Burke's Reflections on the French Revolution and his correspondences are full of such terms.

\footnotetext{
${ }^{34}$ England and Wales. Sovereign. Edward VI, A Proclamation.

35 Peter Heylin, A brief and moderate answer to the seditious and scandalous Challenge of H. Burton (London: Ric. Hodgkinsonne, 1637).

36 Reid, On the Danger, 10.
} 
Over time, the argument on private opinion developed a new twist. Private opinion is the opposite of nature, the natural order or principle. Innovation substitutes "le caprice individuel à la raison universelle” [individual caprice for universal reason], writes Antoine-Chrysostome Quatremère-de-Quincy (1755-1849), archeologist and critic of arts, and Secretary at the French Royal Academy of Fine Arts; “chacun se fait l'unique arbitre de son goût” [Each one makes himself the sole arbiter of his tastes]. ${ }^{37}$

\section{Pathos}

A second type of argument used against innovation is pathos. Pathos is appeal to emotions. Like ethos, it takes many forms. The basic one is appeal to danger, fear and threats (argument ad baculum). ${ }^{38}$ Innovation of religion and republic is "dangerous”, claims Burton: political innovation leads to tyranny and religious innovation to ruin, trouble and discontent. ${ }^{39}$

Danger connotes the disastrous effects of innovation. The argument makes use of analogies with history and other countries - after the French Revolution France often serves as example. One basic form of appeal to emotions is the chain reaction or slipperyslope argument ${ }^{40}$ - the principle of the ancient Greeks' that small causes have great effects. Innovations start little by little, by degrees, “scarce to be perceived”, accumulate, then degenerate into a general catastrophe: "there is no end in sight"; "what will come next?” The argument is used in almost every pamphlet, religious and political, Burton again being no exception: innovators change a kingdom into a tyranny little by little, and change laws, thus leading the country to civil wars. Burton uses Aristotle's Politics (Book $\mathrm{V}$, viii) (not Republic as he erroneously suggests) in which the Greek author “compares changes in a State, which at first seeme but small and insensible, to the expenses of a

\footnotetext{
${ }^{37}$ Antoine-Chrysostome Quatremère-de Quincy, De l'invention et de l'innovation dans les ouvrages des beaux-arts (Paris, F. Didot, 1828), 10, 14.

38 Douglas Walton, Scare Tactics: Arguments that Appeal to Fear and Threats (Dordrecht: Kluwer Academic Publishers, 2000).

${ }^{39}$ Burton, For God and the King, 93, 95.

${ }^{40}$ Douglas Walton, Slippery Slope Arguments (Oxford: Clarendon Press, 1992).
} 
house, and the wasting of a man's substance by little and little, which in a short time consumes all”. ${ }^{41}$

A second form of appeal to emotions is the use of epithets and associations. Associations from heresy to revolution, as sudden and violent, abound in the discourses on innovation. 42 Accusations are also made against the character or morals of the innovator (ad hominem argument), using stereotypes and hyperboles. In general a writer multiplies the terms in order to stress his case. In one single phrase or page one finds a series of epithets one after the other.

A final form of appeal to emotions is equating innovation to fashion, thus discrediting the seriousness of the innovator. Use of the terms "spirit" or "age" of innovation and "love of novelty” are legion among opponents of innovation. Novelty for novelty's sake is also a recurrent accusation.

To the ethos and pathos arguments the accused replies with two positions. The innovator always denies he innovates. As Burton puts it: prelates "doe plead that they bring in no changes, but revive those things which ancient Canons have allowed and prescribed ... Innovations, Say they? Wee bring no innovations, no new rites, but what hath beene in use ever since the Reformation”. ${ }^{43}$ Innovation is return to primitive ages or purity, restoration of the old, reformation. "It is no innovation to admit tradition", claims Christopher Dow against Burton. ${ }^{44}$ "The Church of England [only] did reform the errors and abuses of Rome..."; ${ }^{45}$ discipline "continues in the old and troden steps of religious justice". ${ }^{46}$ Another opponent to Burton, Heylin, replies: "We introduced no novelties ... but onely laboured to reduce [the Church] to that estate and quality, whereby she was in her originall beauty and the Primitive times", "a restitution of those ancient orders, which

\footnotetext{
${ }^{41}$ Burton, For God and the King, 93-99.

${ }^{42}$ Melvin Lasky suggests that innovation is a precursor term to revolution (Melvin S. Lasky, Utopia and Revolution (Chicago: University of Chicago Press, 1976), 311. I would say rather that innovation (as sudden and violent) simply has connotations of revolution.

${ }^{43}$ Burton, For God and the King,158-59.

${ }^{44}$ Dow, Christopher, Innovations Unjustly Charged upon the Present Church and State (London: John Clark, 1637), 167.

${ }^{45}$ Dow, Innovations, 50.

${ }^{46}$ Ibid,, 108.
} 
were established at the Reformation”. To Heylin, “All those innovations which they have charged upon the Church in their scandalous pamphlets, are but a reviver and continuance of the antient usages which have been practiced in the Church since the Reformation and were commended to it from the purest age"; ${ }^{47}$ the king only "labours to suppress those innovations which you and those of your discent have introduced". 48

No one put such a vision better than Edmund Burke: "To innovate is not to reform". ${ }^{49}$ Reform is return to the spirit of the existing laws and constitution and a strict adherence to them, without abandoning first principles. ${ }^{50}$ If there be innovation, it should be gradual, as Francis Bacon suggested 150 years before on imitating nature (time). ${ }^{51}$

The second position held by innovators is to play down innovation. Innovation is "pretended" innovation. It is less an innovation than it seems. There is "nothing of the substance of God worship ... [Innovations in ceremonies] are reverence, external” only, claims Dow against Burton. ${ }^{52}$ New postures are not “of vital importance”, repeats Robert Lee against his accusers from the Church of Scotland; ${ }^{53}$ reading prayers from a book is a "very insignificant matter". ${ }^{54}$ Yet, replies the accuser, "Although the keeping or omitting of a ceremony, in itself considered, is but a small thing, yet the willful and contemptuous transgression and breaking of a common order and discipline is no small offence before God”. 55

\footnotetext{
${ }^{47}$ Heylin, A brief and moderate answer, 140.

${ }^{48}$ Ibid, 82.

${ }^{49}$ Burke, Edmund, A Letter to a Noble Lord, in Daniel E. Ritchie (ed.), Burke, Edmund. Further Reflections on the Revolution in France (Liberty Fund, Indianapolis, Indiana [1991], 1796), 290.

${ }^{50}$ Symmons, John, Reform without Innovation: or, Cursory Thoughts on the Only Practicable Reform of Parliament, Consistent with the existing Laws and the Spirit of the Constitution (London: William Savage, Bedford Bury, 1810), 17.

${ }^{51}$ Francis Bacon, Of Innovations, in The Essays, or Councils, Civil and Moral, in Brian Vickers (ed.), Francis Bacon: The Major Works (Oxford: Oxford University Press [1996] 1625).

52 Dow, Innovation ,113-14.

${ }^{53}$ Robert Lee, Reform Not Innovation: Defense of The Rev. Dr Robert Lee, and Reply to the 'Examination of His Speech by Observer (Edinburgh: Myles Macphail, 1867), 7.

${ }^{54}$ Robert Lee , A Letter to the Members of the ensuing General Assembly [in reference to a "Finding" of the Assembly respecting certain innovations imputed to the writer] (Edinburg, 1867), 25.

${ }^{55}$ Church of England, Constituion and Canons.
} 
In addition to denying or minimizing innovation, the accused returns the accusation to the accuser: "YOU are the innovator", claims Heylin against Burton. ${ }^{56}$ Similarly, "Those who denounce me”, charges Lee, “are themselves chargeable with even greater transgression of a similar kind”. ${ }^{57}$

\section{Logos}

"No man who attacks the errors of his age, and proposes reform, can escape the ordeal of persecution”. So John Patterson, in one of the first full-length positive visions of innovation, summarized the spirit of innovation in the mid-Nineteenth century. ${ }^{58}$ Already in the late Seventeenth century, Guillaume Cave, an English doctor of theology and chaplain of Charles II, put it similarly in his La religion des anciens Chrétiens (1671), translated into French in 1711: “La persuasion de l’antiquité est si grande, \& si forte qu'on croit quel que fois commettre une espèce d'impiété, quand on la révoque en doute, ou que l'on se met en devoir de s'en informer [The influence of antiquity is so great and so strong that we sometimes believe we commit a sort of impiety, when we cast doubt upon it, or when we undertake to inform ourselves about it]. 59

To ethos and pathos, a new generation of writers in the Nineteenth Century offers arguments based on "reality", by way of definitions, analogies with the past and examples from contemporary history. Progress (utility and benefits) is the basic form of the argument. Such an argument emerged slowly in the Eighteenth Century and multiplied in the Nineteenth. To innovation as the source of bloody revolutions, the man of a modern mind responds with the idea of progress.

Yet, progress is one and only one argument developed to rehabilitate innovation. Writers also confront ethos and pathos directly, offering opposite arguments. Against ethos,

\footnotetext{
${ }^{56}$ Heylin, A brief and moderate answer, 38 and 170.

${ }^{57}$ Lee, A Letter, 4.

58 John Patterson, Innovation Entitled to a Full and Candid Hearing (New York: Fowlers and Wells, 1850), 37.

${ }^{59}$ Guillaume Cave, De l'innovation qui étoit imputée au Christianisme, in G. Cave (ed.), La religion des anciens Chrétiens, dans les premiers siècles du Christianisme, Volume 1 (Amsterdam: Jaques Desbordes, 1673: 18-33), 23-24.
} 
writers argue that innovation is a prejudice, a habit, a kind of "blind obstinacy with which the generality of mankind adhere to those doctrines, opinions, and usages which they have inherited from ancestors”. ${ }^{60}$ On a moderate reform bill proposed by William Pitt, then backbencher but soon to be English Prime Minister, the first of a series of measures of parliamentary reform culminating in the Reform Bill of 1832, Charles James Fox, Secretary of State for Foreign Affairs, claims: "To talk of innovation as a bugbear against improvement and reformation, is what uncandid men have always done in politics and religion”. ${ }^{61}$ In his Essai sur les préjugés, Paul-Henri Thiery d'Holbach writes of innovation as a maxim of stupidity and tyranny. ${ }^{62}$

Writers also confront pathos directly. With time, many people came to believe that innovation is first of all a word, a word used for polemical purposes. Innovation is a linguistic weapon used against an enemy: the revolutionary, the Republican and, in the Nineteenth century, the social reformer or socialist. People started to mock the critics of innovation. "The word innovation is so extremely offensive, that like a harsh note in music, it is grating to the feelings of all who hear it: antiquity and old precedents are now in fashion, and must upon all occasions be quoted”. So spoke Reverend Samuel John Nash in England in his Address to the Board of Agriculture. ${ }^{63}$

Nash was right. The word innovation is offensive ... and much more. "On tremble au seul mot d'innovation“[we cringe at the very word innovation]; ${ }^{64}$ a "mot maudit” [a damned word], as the fourierist Victor Considerant put it; 65 “on abuse singulièrement aujourd'hui du mot innovation" [we particularly abuse the word innovation these days]. Innovation is only a "préjugé” [prejudice], “une maxime de la stupidité et de la tyrannie” [the byword

\footnotetext{
${ }^{60}$ Patterson, Innovation Entitled, 17.

${ }^{61}$ Charles James Fox, Speech of Mr. Fox in Favor of Mr. Grey's Motion for Parliamentary Reform, Delivered in the House of Commons, May 26, 1797, in Chauncey A. Goodrich (ed.), Select British Eloquence: Embracing the Best Speehces of Great Britain for the Last Two Centuries ... (New York: Harper \& Brothers [1852], 1797: 515-28), 516.

${ }^{62}$ Pierre-Henri Thiry Holbach, Essai sur les préjugés, ou de l'influence des opinions sur les moeurs et sur le bonheur des hommes (Paris: Niogret, [1822] 1770), 141-43.

${ }^{63}$ Samuel John Nash , An Address to the Board of Agriculture on the Subject of Enclosure and Tithes (Oxford, Printed and sold by R. Slatter, 1800), 2.

${ }^{64}$ Gaspard-Louis Rouillé d'Orfeuil), Innovation, in L'alambic des Loix, ou observations de l'ami des François. sur l'homme et les loix (Morocco: Hispaan, 1773), 76-77.

${ }^{65}$ Victor Considerant, Destinée sociale, Volume I (Paris: Librairies du Palais-Royal,1834), 312.
} 
of stupidity and tyranny]. 66 "Mankind are dupes of words", claims Lee in his defense against the Church of Scotland. "Words admit of different interpretations". ${ }^{67}$ To many, the "reproche d'innovation" [reproaching innovation] is only "une crainte peu réfléchie" [an unthinking fear], 68 that of an "esprit borné" [short-sided mind]. 69 "From this appeal”, concluded an anonymous writer, “there is no appeal”. ${ }^{70}$

Jean le Rond d'Alembert (1717-1783) summarizes the uses made of innovation perfectly. Innovation is a cry, "le cri de guerre des sots” [the war cry of fools”]. In his Éloge de L'Abbé François Régnier Desmarais, (1786), d'Alembert asks why organizations [Corps] have "moins de sens \& de lumières que les particuliers" [lee meaning and enlightenment than individuals]. It is because: ${ }^{71}$

elles craignent le plus léger changement dans leurs principes, leurs opinions, leurs usages ... [D]ès qu'on propose une chose nouvelle, quelque raisonnable qu'elle soit, le cri de guerre des sots est toujours, c'est une innovation. Il n'y a, disait un homme d'esprit, qu'une réponse à faire à cette objection, c'est de servir du gland à ceux qui la proposent; car le pain, quand on a commencé d'en faire, était une grande innovation [they fear the least change in their principles, their opinions, their usages...(A)s soon as someone proposes a new thing, however reasonable it may be, the war cry of fools is always, it is an innovation. There is, to a man of spirit, only one answer to be made to this objection, and that is to serve acorns to those who propose it; since bread, when it was begun to be made, was a major innovation].

\footnotetext{
${ }^{66}$ Cyprien Desmarais, Le temps présent, ou essais sur l'histoire de la civilisation au dix-neuvième siècle (Paris: Ladvocat, Ponthieu, 1826), 116.

${ }^{67}$ Lee, A letter , 47: "The very term "Innovation" carries with it an invidious inference. That word suggests the mischievous policy of those, who at various periods have endeavoured to place upon the Church a yoke of forms and ceremonies which it could not hear ... The changes ... are associated with memories which cannot but render them objects of suspicion [the five articles of Perth, the canons of Archbishop Laud] ... The invidious term has even a more odious tendency. It hints, not darkly, at endeavours to undermine the purity or worship and would fasten the suspicion on the public mind, (as it actually has done on the mind of individuals) that those favourable to change, must be actuated by motives of unfaithfulness to the interests of that Church of which they are member”, 5, 28.

${ }^{68}$ Isaac de Beausobre, Introduction générale à l'étude la politique, des finances et du commerce, volume 2 (Brussels: B. Le Francq, 1791), 52.

${ }^{69}$ Louis-Sébastien Mercier, Fragments de politique et d'histoire, volume 1 (Paris, 1792).

${ }^{70}$ Anonymous (Decius), Innovation, Part VI and VII of a series of articles entitled Pickings from Common Bones, The Universalist Union, 9 (6): 388-90 and 404-406, 1844). Similar accusations abound in England: cry of innovation, disease of the mind, deadly poison, conduct worthy of children.

${ }^{71}$ Jean le Rond d'Alembert, Histoire des membres de l'Académie française, morts depuis 1700 jusqu'en 1771, pour servir de suite aux éloges imprimés \& lus dans les Séances publiques de cette Compagnie, tome 3 (Amsterdam: Moutard, 1786), 293.
} 
That innovation is subjective and admits of nuances gave rise to classifications or typologies - good/bad innovation, ${ }^{72}$ graduées/brusques [gradual/ abrupt], ${ }^{73}$ qui dure/qui ne dure pas [that last/that do not last], ${ }^{74}$ speculative/empirical/practical ${ }^{75}$ - and to nuances: "Not to cling to anything ancient because it has the sanction of time and authority; not to reject anything new because it is destitute of those sanctions". ${ }^{76}$

Re-reading of history - the Reformation was innovation; the revolution was innovation, in a positive sense ${ }^{77}$ - and re-description of what innovation is ${ }^{78}$ gave rise to the rehabilitation of the concept. Such is the fate of many other concepts like imagination, originality, curiosity and revolution. In 1814, François Monlosier (1755-1838), counterrevolutionary, deputy (noblesse) at the General Estates of 1789, produced De la monarchie française at the request of Napoléon Bonaparte. Nevertheless, the document was forbidden by the Empire regime. On over 40 pages, Montlosier relates the history of the different political and economic reforms proposed before 1789 (Maupeou, SaintGermain, Turgot, Necker, de Calonne, Brienne). All have failed, according to Montlosier. because the measures adopted have not respected nor built on the tradition. Yet, Montlosier calls these reforms innovations, in a neutral sense, and applies the word to the revolution too.

\footnotetext{
${ }^{72}$ Encyclopédie, ou dictionnaire raisonnée des sciences, des arts et des métiers, art. Novateur, Volume 11 (Lausanne, Sociétés typographiques, 1765), 254; William Cobbett, A Letter to the People of Hampshire: What Does Wild Innovation Mean? A List of Innovations. Surrender of Sinecures, Reprinted in John M. Cobbett and James P. Cobbett, (eds.), Selections from Cobbett's Political Works, Volume V (London: Anne Cobbett [1830] 1817: 130-35; Dictionnaire des sciences médicales, par une Société de médecins et chirurgiens, Innovation (Paris: C. L. F. Panckoucke, 1818: 236-55).

${ }^{73}$ François Dominique de Reynaud de Montlosier, De la monarchie française, depuis son établissement jusqu'à nos jours; ou recherches sur les anciennes institutions françaises, leur progrès, leur décadence, et sur les causes qui ont amené la révolution et ses diverses phases jusqu'à la déclaration d'empire; avec un supplément sur le gouvernement de Buonaparte, depuis ses comencemens jusqu'à sa chute; et sur le retour de la maison de Bourbon, Tome second (Paris: H. Nicolle/A. Édron/Gide fils, 1814).

${ }^{74}$ Pierre Bayle, Dictionnaire historique et critique (Paris: Desoer, [1820] 1740).

${ }^{75}$ Dictionnaire des sciences médicales.

${ }^{76}$ Patterson, Innovation Entitled, 53. Again, Cave offered a similar argument in the Seventeenth Century: “Comme c'est une folie \& une vanité de vouloir s'attacher à de sottes coutumes, \& s'opiniatrer dans une doctrine à cause de son antiquité, c'est aussi une absurdité de rejeter les meilleurs opinions, parce qu'elles sont nouvelles [As it is a folly \& a vanity to wish to adopt foolish customs, \& to persist in a doctrine because of its antiquity, it is also an absurdity to reject the best opinions, because they are new]", Cave, De l'innovation, 18-19).

${ }^{77}$ François Laurent, Études sur l'histoire de l'humanité - La réforme (Paris: C. Marpon et E. Flammarion, 1879).

${ }^{78}$ On re-description, see Quentin Skinner, Visions of Politics, Volumes 1 and 3 (Cambridge: Cambridge University Press, 2002).
} 
Others are more positive in their redescription. Past innovation or long-lasting and beneficial change becomes innovation: "If it had not been for this happy spirit of innovation, what would be the state of mechanics, mathematics, geography, astronomy, and all the useful arts and sciences”. ${ }^{79}$ Opponents of innovation talk of a "spirit” or "age” of innovation and of "radical" (ness). The modern man uses these same words, but with an opposite connotation. To the opponents of innovation, the age of innovation is subversive to the social order, being too radical. The modern man praises this same spirit, precisely because it changes things in a revolutionary way.

This is only some of the revisionist thoughts that figure in the literature of the Nineteenth century. What was innovation has become current usage: the "Government of the Church by bishops was an innovation”; the British constitution “owes its beauty to innovation”, "the great charter and the bill of rights were innovations", "the office of the speaker and the freedom of speech" was too. "Every change is innovation”. James Taylor Coleridge summarizes this rhetorical move rather well: ${ }^{80}$

\begin{abstract}
Ministers professed a sanctified horror at the most distant prospect of innovation. Yet they were themselves the greatest innovators in this Country - they had altered the law of Treason, they had repealed an article in the Bill of rights, and now they were about to justify a measure, which in its immediate consequences would be to vote the House of Commons useless.
\end{abstract}

\title{
A (Semantic) Rehabilitation
}

At the heart of the rehabilitation of innovation lies a semantic rehabilitation - as both a factor and an outcome of changing representations of innovation. The English philosopher Jeremy Bentham (1748-1832), whose works were translated into French by Etienne Dumont very early on, even before some were published in English, authored

\footnotetext{
${ }^{79}$ Charles Pigott, The Jockey Club or a Sketch of the Manners of the Age (London: M. D. Symons, Paternoster-Row, 1792) 171. See also Holbach, Essai sur les préjugés, 143: "Où serions-nous, hélas! Si nos ancêtres avaient eu pour les leurs l'aveugle vénération que l'on exige de nous pour les préjugés antiques? L'homme serait encore sauvage" [Where would we be, forsooth, if our ancestors had had for their ancestors the blind veneration that is required of us for old prejudices? Man would still be a savage].

${ }^{80}$ Samuel Taylor Coleridge, Proceedings in the British Legislature, House of Commons, April $7^{\text {th }} 1796$, in The Collected Works of Samuel Taylor Coleridge, ed. Lewis Patton (London: Routledge [1970] 1792), 262.
} 
such a rehabilitation. Bentham is known above all for his utilitarianism. Today, many understand utilitarianism in strictly economic terms. However, Bentham's utilitarianism is not restricted to commerce - commerce being considered incompatible with republican or civic virtue from the mid-eighteenth century onward. ${ }^{81}$ Bentham's utilitarianism is 'philosophical'. It encompasses the political, social and economic as well as the scientific and technological. It applies to anything that is 'useful' in every aspect of life and society.

Bentham's idea of utility first appeared in An Introduction to the Principles of Morals and Legislation (1789). To Bentham, "Nature has placed mankind under the governance of two sovereign masters, pain and pleasure ... They govern us in all we do, in all we say, in all we think". ${ }^{82}$ Utility is "that property in any object, whereby it tends to produce benefit, advantage, pleasure, good and happiness ... or to prevent the happening of mischief, pain, evil, or unhappiness”. ${ }^{83}$ In sum, utility is the production of (good) effects.

Together with his well-known work on utilitarianism, a fact that is all but forgotten today is that Bentham is also responsible for what may have been the very first full-length rehabilitation of the concept of innovation. Bentham produced pages on innovation in various incomplete manuscripts, first published in French by Etienne Dumont in 1816 as Traité des sophismes politiques - then in English as The Book of Fallacies in 1824 by Peregrine Bingham. In fact, Bentham's ideas acquired a wide audience after the translation into French of (extracts of) The Principles by Dumont in 1802 (Traité de legislation civile et pénale). Then, using other manuscripts (including that on fallacies and the Essays on Political Tactics of 1791), ${ }^{84}$ Dumont rearranged the whole and produced Oeuvres de Jérémie Bentham (1829). ${ }^{85}$

\footnotetext{
${ }^{81}$ John G. A. Pocock, Virtue, Commerce, and History (Cambridge: Cambridge University Press, 1985). For a critique of Pocock's dichotomy, see Shelley Burtt, Virtue Transformed: Political Argument in England, 1688-1740 (Cambridge: Cambridge University Press, 1992).

82 Jeremy Bentham , An Introduction to the Principles of Morals and Legislation (London: W. Pickering [1823] 1789), 1.

${ }^{83}$ Bentham, An Introduction, 3.

${ }^{84}$ Jeremy Bentham, Essay on Political Tactics: Containing Six of the Principal Rules Proper to Be Observed by a Political Assembly, In the Process of Forming a Decision (London: T. Payne, 1791).

${ }^{85}$ Etienne Dumont, Oeuvres de Jérémie Bentham, jurisconsulte anglais (Brussels: Hauman et Co., 1829).
} 
In Dumont's Traité one finds an explicit application of the idea of utility, first explained in The Principles, to the concept of innovation - an application Bentham never made so explicitly except in unpublished manuscripts. In every translation of extracts from Bentham, Dumont always included innovation, as discussed in Bentham's manuscripts, as an example of argumentation based on good reasons or utility. Such is the case with the Traité de legislation, but also with both Tactiques des assemblées legislatives and Traité des sophisms politiques (1816). With these translations, the rehabilitation of innovation was widely diffused in France. ${ }^{86}$

At the very beginning of the Traité, Dumont establishes a link between the political thought of Bentham on laws and innovation: "Qu'est-ce que donner une bonne raison en fait de loi? C’est alléguer des biens et des maux [effects] que cette loi tend à produire” [What is it to give a good reason for making a law? It is to explain the good and bad effects the law tends to produce]. Bentham had already stated the principle of utility, as follows: "the principle which approves or disapproves of every action whatsoever, according to the tendency which it appears to have to augment or diminish the happiness of the party whose interest is in question: or, what is the same thing in other words, to promote or to oppose that happiness". ${ }^{87}$ Then Dumont discusses fallacies that are commonly encountered in legislative affairs. One of these is "reproche d'innovation [the reproach of innovation]”: accusing someone of innovating or rejecting innovation just because it is innovation. "Ceux qui [Those who]", states Dumont, "dans une assemblée politique, ont un grand intérêt à ne pas souffrir l'examen d'une question, s'efforcent de mettre le préjugé seul à la place du raisonnement [in a political assembly have a strong interest in not enduring the examination of a question, strive to put prejudice alone in place of reasoning]”.

\footnotetext{
${ }^{86}$ Bentham drafted several essays dealing with France specifically. In many works too he compared the situations in England and in France. In 1792 he was made an honorary citizen of France. Bentham's writings had no immediate impact. The impact was due to Dumont's early translation of Bentham's works. It has been estimated that by 1830, over 50,000 copies of Dumont's translations had been sold in Europe alone.

${ }^{87}$ Bentham, An Introduction, 2-3.
} 
Such sophisms take many forms, one of which is the fallacy of danger, as Bentham calls it, the subject matter of which is "to repress discussion altogether, by exciting alarm". By using a single word, in this case innovation, the fallacy turns a thing into a monster: anarchy. ${ }^{88}$ This is a special form of the fallacy petition principii, used here employing a single word. "Le mot seul et par lui-même affirme que l'objet auquel on l'applique est un objet d'approbation ou de désapprobation [The word alone and in itself affirms that the object to which it is applied is an object of approbation or disapprobation]". This generally occurs imperceptibly. "A man falls into it but too naturally ... The great difficulty is to unlearn". ${ }^{89}$

Bentham distinguishes three kinds of words: neutral, eulogistic and dyslogistic. Many words begin as neutral (unaccompanied by any sentiment or judgment) - a contestable assessment - then shift to eulogistic (approbation) or dyslogistic (disapprobation). "Originally, all terms expressive of any objects were (it seems reasonable to think) neutral. By degrees they acquired, some of them eulogistic, some a dyslogistic, cast”. ${ }^{90}$ "The person, act, or thing in question is or deserves to be, or is and deserves to be, an object of general approbation; or the person, act, or thing in question is or deserves to be, or is and deserves to be, an object of general disapprobation”. ${ }^{91}$

According to this classification, change is neutral; improvement is eulogistic; and innovation is dyslogistic. Part II of The Book of Fallacies is concerned with fallacies of danger, and Chapter 2 deals specifically with the fallacy of innovation under the title The Hobgoblin Argument, or, No Innovation!. To Bentham, the word innovation is "imputation of bad motives, bad designs, bad conduct and character". 92 "Innovation means a bad change, presenting to the mind, besides the idea of a change, the proposition, either that change in general is a bad thing, or at least that the sort of change in question is a bad change". ${ }^{93}$ But "to say all new things are bad, is as much as to say all

\footnotetext{
${ }^{88}$ Bentham, Book of Fallacies, 144.

${ }^{89} \mathrm{Ibid}, 215$.

${ }^{90}$ Ibidem.

${ }^{91}$ Bentham, Book of Fallacies, 216.

${ }^{92}$ Ibid, 143.

${ }^{93}$ Ibid, 143-44.
} 
things are bad, or, at any event, at their commencement; for of all the old things ever seen or heard of, there is not one that was not once new. Whatever is now establishment was once innovation". ${ }^{94}$ Certainly there is some truth in the fallacy. There may be some reasons to oppose a legislative measure: a new legislative measure "always carries a certain quantity of mischief”. To oppose a measure for mischief constitutes a just reason, if well founded. But generally, the opponent "set up the cry of Innovation! Innovation! hoping by this watchword to bring to his aid all whose sinister interest is connected with his own". ${ }^{95}$ To Bentham, the conservative "pass[es] condemnation on all change" by "the indiscriminating appellative" new. 96 "The horror of innovation", concludes Bentham, "is really a disease". ${ }^{97}$

To Bentham, innovation is an instrument of deception, a linguistic weapon. While discussing another fallacy - the fallacy of confusion, "the object of which is, to perplex, when discussion can no longer be avoided" - Bentham turns to innovation again. Innovation means something new, but "it has contracted a bad sense; it means something which is new and bad at the same time ... [Yet] the idea of novelty was the only idea originally attached to the term innovation, and the only one which is directly expressed in the etymology". The word is "chosen for the purpose of passing condemnation". ${ }^{98}$

Bentham applies his 'language analysis' to a specific type of innovation too, which we call "technological innovation" today. As a "projector" himself (projector is a precursor term to technological innovator), Bentham conceived plans for economic development,

\footnotetext{
${ }^{94}$ Ibid, 144. Two hundred years before, Francis Bacon offered an analogous critique of the use of the word "Antiquity" in Novum Organum (Francis Bacon , Novum Organum, in Rees, G., and M. Wakely (eds.), The Instauratio Magna Part II: Novum Organum and Associated Texts (London: Clarendon Press [2004] 1620, 84).: "Men harbour a very lax view of [Antiquity], and one barely in line with the very word itself ... [Antiquity] ought to denote our times, and not the springtime of the world when the ancients lived. For in relation to ours that time was old and greater, but in relation to the world itself, new and slighter. And just as we expect greater knowledge of human affairs and maturity of judgment from an old man ... so in the same way much greater things could reasonably be expected from our time ... than from the earliest ages”.

${ }^{95}$ Bentham, Book of Fallacies, 147.

${ }^{96}$ Ibid, 149-50.

${ }^{97}$ Ibid, 151.

${ }^{98}$ Ibid, 218-19.
} 
among them a new kind of prison called Panopticon. ${ }^{99}$ Bentham on many occasions denounced the restrictions on investment imposed on projectors by laws on usury. "No laws ought to exist", suggests Bentham in A Manual of Political Economy, "for the restraint of projectors and for preventing them from obtaining loans of the capital of which they stand in need". To Bentham, "the censure that condemns projectors" is "a general attack upon the improvement of the arts and sciences”. ${ }^{100}$ In a sentence reminiscent of that found later in The Book of Fallacies, Bentham states:

Everything which is routine to-day was originally a project; every manufacture, how old soever it may be, was once new; and when new, it was the production of that mischievous and bold race who ought to be destroyed - the race of projectors!

In line with Daniel Defoe before him, Bentham wants to remedy the bad press projectors have and the censure put on them, as satirized in Jonathan Swift for example. Bentham offers many solutions to this end. One is changing the laws on usury. In Defence of Usury, Bentham challenges Adam Smith on the question of "projectors" (Letter XIII). 101 He accuses the economist of having, like most people in England, a pejorative understanding of projects and projectors, ranking the latter with "prodigals" and thus conveying "the idea of reprobation". To Bentham, a project is rather the pursuit of wealth by invention, and always "has this circumstance against it, viz. that it is new". Smith has condemned "as rash and ill-grounded all those projects by which our species have been successively advanced from the state in which acorns were their food, and raw hides their cloathing, to the state in which it stands at present”. For a third time, Bentham refers to the fallacy on innovation and concludes:

Sir, let me beg you, whether whatever is now the routine of trade was not, at its commencement, project? Whether whatever is now establishment, was not, at one time, innovation?

99 J. Crimmins, Political Economy and Projectors: Bentham's Defense of Usury,1998, available at ideashistory.org.ru/pdfs/07crimmins.pdf.

100 Jeremy Bentham , A Manual of Political Economy, Edited from the manuscripts, in The Works of Jeremy Bentham, Volume 3, ed. J. Bowring (Edinburgh: William Tait [1843] 1793-95), 49.

101 Jeremy Bentham, Defense of Usury (London: Payne and Foss, 1787). 
To Bentham, the restraints on usury and interest rates have the effect of diminishing the total number of (potentially beneficial) projects in England. Bentham's proposal is "to provide, in favour of projectors only, a dispensation from the rigour of the anti-usurious laws; such, for instance, as is enjoyed by persons engaged in the carrying trade”. A second solution, reminiscent of Francis Bacon, is for legislators "to encourage inventive industry". ${ }^{102}$ To Bentham, science and arts, "theory and practice" are "combined and inseparable”. ${ }^{103}$ Bentham had already made a distinction between invention and innovation (his terms are talent and project), ${ }^{104}$ one of the first such distinctions, and one that became commonplace in the twentieth century. Despite the distinction, both science and arts are "useful", states Bentham. ${ }^{105}$ Because research increases "the mass of general wealth”, ${ }^{106}$ it is imperative that government fund the research which is necessary for inventions. This solution he developed at length in The Rationale of Rewards. To Bentham, "pure theory [is] the first step in invention", ${ }^{107}$ a rationale which in fact gave rise to linear or sequential "models of innovation" in the twentieth century.

Bentham's third solution was rehabilitating the image of projectors. In Defence of Usury, as we have seen, Bentham applies his language analysis to projects and projectors. He challenges Adam Smith to define what a projector is, what a good as opposed to a bad projector is. In A Manual of Political Economy, Bentham suggests that governments provide charts or lists of inventions in order to distinguish good from bad projects and projectors. And he clarifies the vocabulary, even changes it. "Were it in the power of laws to put words under proscription, as it is to put men, the cause of inventive industry might perhaps derive scarcely less assistance from a bill of attainder against the words project and Projectors, than it has derived from the act authorizing the grant of patents”.

Despite Bentham's concern with “technological innovation” (projects), one cannot attribute to this philosopher the coining of the expression nor its impact on much later

\footnotetext{
102 Bentham, A Manual, 47

103 Jeremy Bentham, The Rationale of Reward (London: Robert Heward, 1830) 204.

${ }^{104}$ Bentham, A Manual, 49-50.

${ }^{105}$ Bentham, The Rationale, $205 \mathrm{f}$.

${ }^{106}$ Ibid, 215.

${ }^{107}$ Ibid, 214.
} 
writings on technological innovation. Although by Bentham's time the term innovation was applied increasingly to fields other than religion and politics, it was left to the writers of the Twentieth century to develop a discourse on technological innovation. Bentham kept to the vocabulary of his time: "project" for technological innovation and "innovation" for introducing change into the established order - Bentham uses innovation only once in matters of projects and projectors.

Bentham admits that the idea of utility is not a new idea. He is right. Several people before him - historians, Parliamentarians, the press - discuss innovation in similar terms. 108 Yet until then, says Bentham, utility was interpreted instinctively or, when discussed openly, essentially criticized. With a treatise on the political rhetoric of his time, whose arguments apply one to one to innovation, Bentham did contribute to a definitive rehabilitation of innovation (as utility or progress). In the following decades, innovation is discussed with increasing frequency as a positive mean to political, social and material progress. 109

\section{Conclusion}

From the Reformation to the Nineteenth Century, innovation is political and contested. As a concept, what constitutes innovation was created by the enemies of innovation. The anxiety about innovation arose first and foremost in religion, Burton being of major

\footnotetext{
${ }^{108}$ An early exponent of the idea is Guillaume Cave in De l'innovation. Cave offers two arguments against those who "pass up the Christian religion for a religion that is modern and that someone has just invented]". One argument is to the effect that all things that exist were new at their beginning. The other argument is progress: "It is certainly natural for Man to prefer the greater to the lesser, that which is useful to that which is not useful". According to Cave, the Christian writer Arnobe (c.240-304) says: "Please, what harm does it do us (that our religion is new)? Can we not ascribe the same fault to the earliest days of the world, that people lived poorly and miserably, until they had little by little arrived at a more magnificent and more illuminated manner of living...It is certainly natural for Man to prefer the better to the worse, that which is useful to that which is not useful”. Second, according to Cave again, Saint-Ambroise (340-397) says: "You say that our religion is new \& yours is old, but...if ours is new, it will age with time, \& yours which is, you say, old, was new for a certain time. One must not measure the goodness or dignity of a religion by the time it has lasted, but by the excellence of its worship".

${ }^{109}$ Godin, The Idea of Innovation.
} 
influence. Other concerns - political and social - flowed from this basic preoccupation a not dissimilar situation to that of the critique of the Enlightenment. ${ }^{110}$

For centuries, the paradigmatic argument against innovation was that it is analogous to heresy. Innovation is a liberty. Yet, with time innovation encompasses much more than a religious connotation. Innovation covers the religious, the political and the social domains. To ecclesiasts, innovation is dangerous. To the political authorities it is conspiracy and subversive of the political order or revolutionary (sudden, violent and radical). To critics of socialism innovation is what many call a "scheme" against the regime of private property.

Over the centuries, the arguments used to talk of innovation shifted from the individual to the social, from individual accountability to social progress. The Twentieth Century has changed the above connotation of innovation to one concerned with economic benefits. To be sure, the idea of innovation as liberty remains in the vocabulary: "initiative" and entrepreneur are keywords. But thoughts on innovation shifted from the individual to organizations and nations as innovators. Innovation is praised for its socioeconomic effects. A new semantic field develops for a new society. In the previous centuries, the semantic field of innovation is composed of four concepts. One is change. Change is accepted, depending on contexts, but not innovation. Innovation (as well as alteration) is intentional change, as contrasted to change which is natural or God. Among the intentional changes, reformation is accepted. Reformation is gradual. It builds on what already exist. A third concept of the semantic field of innovation is revolution. A revolution is radical, violent and total. Over time, innovation encapsulates this later connotation. Innovation is change to the established order, a change that is intentional, a change that brings radical or revolutionary transformations of society.

The semantic field of the $20^{\text {th }}$ century is different. To be sure, some terms were in place in the previous centuries, like change. Innovation is intentional change in the sense of

110 Darrin M. McMahon, Enemies of the Enlightenment: The French Counter-Enlightenment and the Making of Modernity (Oxford: Oxford University Press, 2001), 197. 
planned change. It necessitates strategy and investment. Innovation also retains the idea of revolution. There are revolutionary or major innovations, so it said, and these are the most studied innovations because of their impacts on society, so it is believed. Yet, a new vocabulary develops. Innovation is originality. Innovators are the firsts to adopt a new practice, particularly the firsts to commercialize a new invention.

Innovation has become a powerful cultural force invested with emotional intensity and enthusiasm. Many of our concepts, suggests Gordon Schochet, have an "irreducible evaluative content or function. They are used rhetorically or persuasively, not descriptively". ${ }^{111}$ Innovation is a word used for both acts of condemnation (before the Nineteenth Century) and acts of praise (Twentieth Century).

${ }^{111}$ Gordon J. Schochet, Why Should History Matter? Political Theory and the History of Discourse, in J. G. A. Pocock (ed.), The Varieties of British Political Thought, 1500-1800 (Cambridge: Cambridge University Press, 1993) 354. 